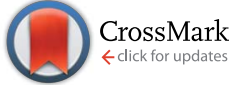

Cite this: RSC Adv., 2014, 4, 56200
Received 26th August 2014 Accepted 23rd October 2014

DOI: $10.1039 / c 4 r a 09305 d$

www.rsc.org/advances

\section{Effect of pretreatment and temperature on the properties of Pinnularia biosilica frustules}

\author{
Erik Van Eynde, ${ }^{\text {*a }}$ Britt Lenaerts, ${ }^{a}$ Tom Tytgat, ${ }^{a}$ Sammy W. Verbruggen, ${ }^{\text {ab }}$ \\ Birger Hauchecorne, ${ }^{a}$ Ronny Blust ${ }^{c}$ and Silvia Lenaerts ${ }^{a}$
}

\begin{abstract}
Diatoms are unicellular microalgae that self-assemble an intricate porous silica cell wall, called frustule. Diatom frustules possess a unique combination of physical and chemical properties (chemical inertness, high mechanical strength, large surface area, low density, good porosity and highly ordered features on the nano-to-micro scale) making diatom frustules suited for many nanotechnological applications. For most proposed applications the organic material covering the frustules needs to be removed. In this paper we investigate the effect of different frustule cleaning methods (drying, autoclavation, SDS/EDTA treatment, $\mathrm{H}_{2} \mathrm{O}_{2}$ treatment and $\mathrm{HNO}_{3}$ treatment) and subsequent heat treatment at different temperatures $\left(105{ }^{\circ} \mathrm{C}, 350{ }^{\circ} \mathrm{C}, 550{ }^{\circ} \mathrm{C}\right.$ and $\left.750{ }^{\circ} \mathrm{C}\right)$ on the material characteristics of the diatom Pinnularia sp. Material characteristics under study are morphology, surface area, pore size, elemental composition and organic content. The cleaned Pinnularia frustules are subsequently investigated as adsorbents to remove methylene blue (MB) from aqueous solution.
\end{abstract}

\section{Introduction}

Porous silica materials exhibit excellent chemical and mechanical properties for use in a broad range of applications. ${ }^{1}$ During the last decades, material scientists have put in a lot of effort to develop new porous siliceous materials using various chemical synthesis routes. ${ }^{2}$ These structures exhibit excellent properties such as elevated surface area, high thermal and hydrothermal stability and controlled pore size which can be used in applications for light harvesting, chromatography, catalysis, drug delivery, photonics, biosensors and adsorption. ${ }^{\mathbf{1} 3-\mathbf{8}}$

Besides the chemical approaches to develop porous silica, nature also provides numerous biomineralised micro-tonanostructures with 3D shapes which have been optimized during earth's evolution. A siliceous material of particular interest is biosilica produced by diatom microalgae. ${ }^{9}$ Diatoms are an extremely diverse group of unicellular algae that selfassemble a porous, intricate siliceous cell wall, called frustule. The frustule is composed of two overlapping valves which are reproduced during cell division. They are kept together by a

${ }^{a}$ Research Group Sustainable Energy and Air Purification, Department of Bioscience Engineering, University of Antwerp, Groenenborgerlaan 171, 2020 Antwerp, Belgium. E-mail: erikvaneynde@uantwerpen.be

${ }^{b}$ Centre for Surface Chemistry and Catalysis, Department of Microbial and Molecular Systems, Catholic University of Leuven, Kasteelpark Arenberg 23, B-3001 Heverlee, Belgium

${ }^{c}$ Systemic Physiological and Ecotoxicological Research (SPHERE), University of Antwerp, Groenenborgerlaan 171, 2020 Antwerp, Belgium girdle band. The frustule has an ordered 3D structure which contains pores with nano-to-microscale features. ${ }^{9-13}$

Diatom cells take up soluble silicic acid $\left(\mathrm{Si}(\mathrm{OH})_{4}\right)$ from the environment which is precipitated during cell division into amorphous silica within a specialized intracellular compartment called the silicon deposition vesicle (SDV). The SDV contains specialized proteins called silaffins and long chain polyamines which will assist with the formation and patterning of the silica nanostructures. ${ }^{13}$ After the formation of the patterned silica these macromolecules remain tightly associated with the biosilica. The siliceous cell wall is embedded in an organic matrix that avoids dissolution in the aqueous environment. ${ }^{\mathbf{1 2}}$

For most proposed nanotechnological applications the organic matter covering the frustule should be removed. ${ }^{\mathbf{1 0 , 1 1}}$ In literature, different cleaning methods for frustules are described. The most frequently employed methods are high temperature ashing, hydrogen peroxide treatment, acid treatment and SDS/EDTA treatment. ${ }^{\mathbf{1 4 - 1 7}}$ Harsh treatments like nitric acid and hydrogen peroxide are thought to cause selective etching of the frustule surface, whereas soft methods do not remove all the organic matter. In this paper the effect of different cleaning methods on the material characteristics of Pinnularia frustules is investigated. Material characteristics under study are the BET surface area, pore size distribution, the organic content and the elemental composition of the cleaned frustules. The change in material properties could impact the suitability for some applications. In this paper adsorption capacity towards methylene blue is studied. 


\section{Experimental section}

\section{Diatom cultivation}

The freshwater diatom specie Pinnularia sp. (MIC 9-8) was obtained from the DCC culture collection (Ghent, Belgium) and was grown in freshwater WC medium. The nutrient composition of the medium is described in detail by Van Eynde et al. (2013). ${ }^{18}$ Pinnularia sp. was cultured in $1 \mathrm{~L}$ photobioreactors aerated with sterile air at $20{ }^{\circ} \mathrm{C}$ using a $16 \mathrm{~h}$ light $/ 8 \mathrm{~h}$ dark cycle. In order to obtain high biomass concentration the cultivation medium is refreshed daily. Daily refreshment was performed by allowing diatoms cells to settle at the bottom of the reactor in non-aerated conditions for 1 hour, subsequently remove the upper medium layer (approximately 800-900 mL) by decantation and replenish the culture with fresh WC-medium. The living diatoms were harvested after 2-3 weeks of culturing. The harvested Pinnularia cells were centrifuged and washed several times with distilled water to remove all medium compounds.

\section{Preparation of the cleaned, heat treated frustules}

The cleaning of organic matter covering the siliceous frustule was carried out using five different pretreatment methods. The applied methods are drying, autoclavation and chemical treatment with SDS/EDTA, $\mathrm{H}_{2} \mathrm{O}_{2}$ or $\mathrm{HNO}_{3}$. Drying was performed by placing a $20 \mathrm{~mL}$ aliquot of the harvested and washed Pinnularia cells in an oven at $70{ }^{\circ} \mathrm{C}$ until all water was evaporated. The autoclavation treatment was performed by placing a $20 \mathrm{~mL}$ aliquot of the harvested Pinnularia cells in an autoclave at $121{ }^{\circ} \mathrm{C}$ and 1 bar. The autoclaved cell suspension was subsequently centrifuged, washed with distilled water and dried at 70 ${ }^{\circ} \mathrm{C}$. In the chemical treatments of the harvested Pinnularia cells a $20 \mathrm{~mL}$ aliquot is mixed with $\mathrm{H}_{2} \mathrm{O}_{2}, \mathrm{HNO}_{3}$ or SDS/EDTA to reach a final concentration of respectively $15 \% \mathrm{H}_{2} \mathrm{O}_{2}, 30 \%$ $\mathrm{HNO}_{3}$ or $0.1 \mathrm{M} \mathrm{SDS} /$ EDTA. The chemical treatments were performed at $60{ }^{\circ} \mathrm{C}$ for $48 \mathrm{~h}$. The cleaned frustules were subsequently centrifuged, washed with distilled water and dried at 70 ${ }^{\circ} \mathrm{C}$.

The as pretreated Pinnularia frustules were subsequently heat treated at 4 different temperatures: $105{ }^{\circ} \mathrm{C}, 350{ }^{\circ} \mathrm{C}, 550{ }^{\circ} \mathrm{C}$ and $750{ }^{\circ} \mathrm{C}$. By applying five different pretreatment methods (drying, autoclavation, $\mathrm{HNO}_{3}, \mathrm{H}_{2} \mathrm{O}_{2}$ and SDS/EDTA) onto harvested Pinnularia cells and treat these samples at four different temperatures $\left(105,350,550\right.$ and $\left.750{ }^{\circ} \mathrm{C}\right) 20$ different Pinnularia frustule powder samples were obtained which will be characterized and tested for methylene blue adsorption.

\section{Material characterization}

Scanning electron microscopy (SEM) was performed using a JEOL JSM-5510 system operating at an acceleration voltage of 15 $\mathrm{kV}$. FTIR analyses were performed using Thermo NicoletTM 6700 (Thermo Fisher Scientific). Potassium bromide (KBr) was used as a matrix for the diatom samples. $\mathrm{N}_{2}$ adsorption/ desorption measurements were performed at $-196{ }^{\circ} \mathrm{C}$ using a Micromeretics Tristar 3000 equipment. The isotherms were measured after degassing of the samples for $24 \mathrm{~h}$ at $100{ }^{\circ} \mathrm{C}$. The surface area was calculated using the BET-equation and the pore size distribution was determined by the BJH method. Thermogravimetric analysis (TGA) was performed with a Q500 V6.7 build 203 apparatus at a linear temperature ramp of $5{ }^{\circ} \mathrm{C}$ $\min ^{-1}$. The elemental composition of the Pinnularia frustules was determined with ICP-MS using Varian Expert 700 quadrupole ICP-MS instrument. Before ICP-MS analysis the diatom samples were destructed by fusing with $\mathrm{NaOH}$ at $650{ }^{\circ} \mathrm{C}$ and dissolved in diluted nitric acid.

\section{Adsorption experiments}

Methylene blue (MB) was selected as a model system to study the adsorption process of dyes onto Pinnularia frustules. Adsorption experiments were performed by adding a fixed amount of $10 \mathrm{mg}$ diatom frustules to $20 \mathrm{~mL}$ of dye solutions with variable concentrations $\left(5-40 \mathrm{mg} \mathrm{L}^{-1}\right)$. In order to obtain a good contact between $\mathrm{MB}$ and the diatom frustules, adsorption experiments were conducted on a stir plate at an agitation speed of $500 \mathrm{rpm}$. Moreover, the temperature was kept constant at $20{ }^{\circ} \mathrm{C}$ to attain equilibrium conditions. All experiments were conducted for $16 \mathrm{~h}$, while the changes in absorbance of the dye were determined at equilibrium. For these measurements, 1.5 $\mathrm{mL}$ of the dye solutions were centrifuged for $1 \mathrm{~min}$ in a Beckmann coulter centrifuge at $12500 \mathrm{rpm}$ so that the sorbent could be separated from the solution. Consequently, the residual dye concentration in aqueous solution was then determined at the maximum wavelength of $\mathrm{MB}$, i.e. $664 \mathrm{~nm}$, using a Shimadzu UV2501PC spectrophotometer. The amount of MB adsorbed by Pinnularia frustules at equilibrium, $q_{\mathrm{e}}\left(\mathrm{mg} \mathrm{g}^{-1}\right)$, was calculated from the following equation:

$$
q_{\mathrm{e}}=\frac{C_{0}-C_{\mathrm{e}}}{m_{\mathrm{s}}}
$$

where $C_{0}$ and $C_{\mathrm{e}}$ are the initial MB concentration and the MB concentration at equilibrium $\left(\mathrm{mg} \mathrm{L^{-1 }}\right)$, respectively. The concentration of calcined Pinnularia frustules $\left(\mathrm{g} \mathrm{L}^{-1}\right)$ is denoted with $m_{\mathrm{s}}$.

\section{Adsorption isotherms}

Adsorption isotherms are determined to study the adsorption process. The adsorption isotherm describes the interaction between adsorbate and adsorbent. In literature, numerous isotherm equations have been reported. ${ }^{19-21}$ The experimental data obtained were evaluated by two commonly used adsorption isotherms, i.e. the Langmuir and Freundlich isotherm. The Langmuir adsorption isotherm is used to model monolayer adsorption on a surface with identical, homogenous distributed adsorption sites. It can be expressed as:

$$
q_{\mathrm{e}}=\frac{Q_{0} K_{\mathrm{L}} C_{\mathrm{e}}}{1+K_{\mathrm{L}} C_{\mathrm{e}}}
$$

where $C_{\mathrm{e}}$ is the equilibrium MB concentration in the system (mg $\left.\mathrm{L}^{-1}\right), q_{\mathrm{e}}$ is the amount of $\mathrm{MB}$ absorbed at equilibrium $\left(\mathrm{mg} \mathrm{g}^{-1}\right)$, $K_{\mathrm{L}}$ is the Langmuir isotherm constant and $Q_{0}\left(\mathrm{mg} \mathrm{g}^{-1}\right)$ gives the maximum adsorption capacity of the adsorbent. A good fit of this equation reflects monolayer adsorption. Conversion of eqn (2) to a linear expression results in following equation: 


$$
\frac{1}{q_{\mathrm{e}}}=\left(\frac{1}{K_{\mathrm{L}} Q_{0}}\right) \frac{1}{C_{\mathrm{e}}}+\frac{1}{Q_{0}}
$$

The values of $Q_{0}$ and $K_{\mathrm{L}}$ are calculated from the slope and the intercept of the linear plot of $1 / q_{\mathrm{e}}$ versus $1 / C_{\mathrm{e}}$. The obtained values of the Langmuir adsorption capacity are given in Table 3. The Freundlich isotherm equation on the other hand, assumes that the adsorbent has a heterogeneous surface and is given below:

$$
q_{\mathrm{e}}=K_{\mathrm{F}} C_{\mathrm{e}^{\frac{1}{n}}}
$$

where the Freundlich constant $K_{\mathrm{F}}$ is an indication of the multilayer adsorption capacity and $1 / n$ is the adsorption intensity. The magnitude of the exponent, $1 / n$, provides an indication of the favorability of adsorption. Values of $n>1$ represent favorable adsorption conditions. The logarithmic conversion of the Freundlich isotherm results in the linearized expression:

$$
\ln q_{\mathrm{e}}=\ln K_{\mathrm{F}}+\frac{1}{n} \ln C_{\mathrm{e}}
$$

\section{Results and discussion}

\section{Material characterization}

TGA. Living Pinnularia diatoms contain a siliceous cell wall embedded in an organic matrix. ${ }^{12}$ The organics covering these frustules are removed by different cleaning methods. The used methods are nitric acid $\left(\mathrm{HNO}_{3}\right)$, hydrogen peroxide $\left(\mathrm{H}_{2} \mathrm{O}_{2}\right)$, SDS/ EDTA, autoclavation $\left(121{ }^{\circ} \mathrm{C}, 1\right.$ bar $)$ and drying. Treatment of Pinnularia cells with $\mathrm{HNO}_{3}$ and $\mathrm{H}_{2} \mathrm{O}_{2}$ result in oxidative digestion of the organic matter. SDS/EDTA treatment causes denaturation of proteins and dissolution of organics. Thermogravimetric analysis is performed to study the remaining organic content after pretreatment. Fig. 1A shows the weight loss of the different pretreated samples as a function of temperature. TGA reveals that after chemical treatment of the Pinnularia cell, some organics still remain attached to the frustules. Heat treatment could remove an additional 11, 7 and $10 \mathrm{wt} \%$ of the $\mathrm{HNO}_{3}, \mathrm{H}_{2} \mathrm{O}_{2}$ and SDS/EDTA treated samples respectively. The pretreatment methods autoclavation and drying do not remove organics. The organic content of the dried and autoclaved frustules is only removed by the subsequent calcination. Fig. 1B shows the derivative of the TGA weight loss curve which reveals that for all pretreatment methods the largest organic fraction is removed around $300{ }^{\circ} \mathrm{C}$. For dried and autoclaved Pinnularia frustules a second release peak at $450{ }^{\circ} \mathrm{C}$ is also observed. At temperatures above $550{ }^{\circ} \mathrm{C}$ no further decrease in weight loss is detected, indicating that no organic fraction is left at these temperatures. The weight loss in autoclaved and dried Pinnularia frustules is 54 and $48 \mathrm{wt} \%$ respectively, which means that the silica frustule is responsible for almost half of the weight of the cell. A diatom silica content of approximately $50 \mathrm{wt} \%$ has been previously described in literature. Although most studies report diatom silica content values between 5 and 15 wt\%, Lund (1965) reported that the freshwater diatom Melosira granulata contains
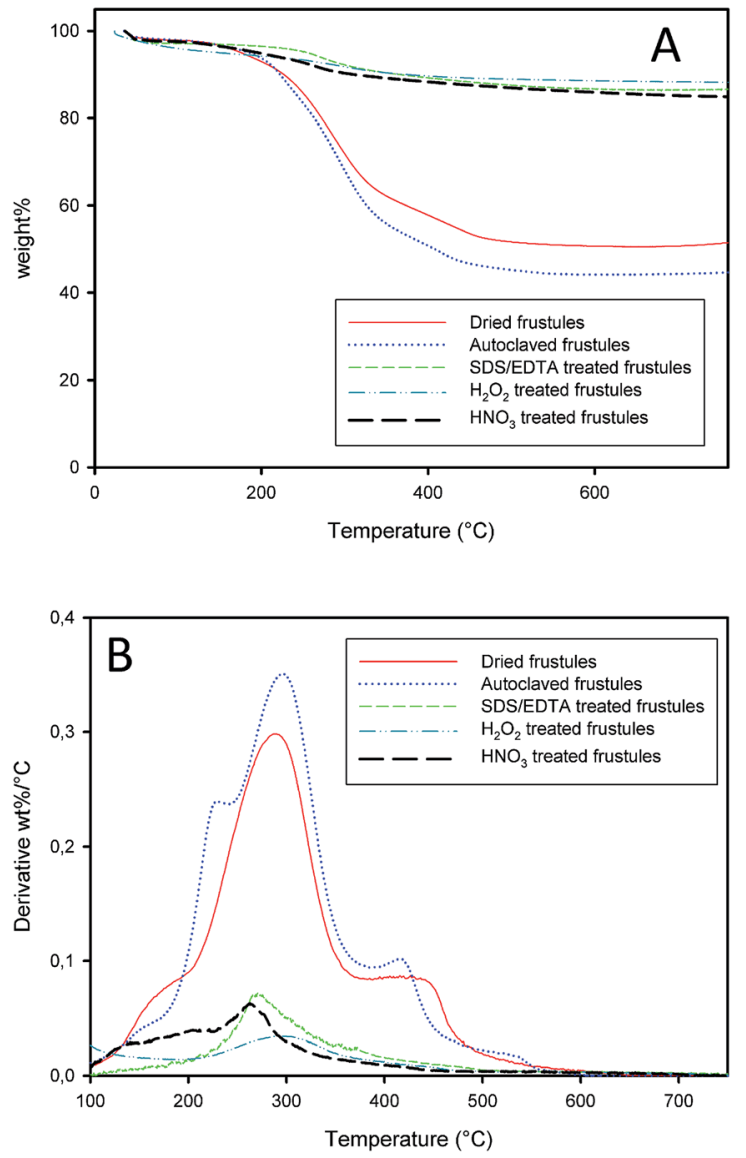

Fig. 1 (A) TGA curve and (B) derivative TGA curve of pretreated Pinnularia frustules.

54 wt\% silica. ${ }^{22}$ Also, Sicko-Goad et al. (1984) determined silica content in 13 freshwater diatom species and found values ranging from $39 \mathrm{wt} \%$ to $78 \mathrm{wt} \%{ }^{23}$

\section{Surface area and pore size distribution}

One of the most attractive properties of diatom frustules is its porous inorganic structure. ${ }^{10} \quad \mathrm{~N}_{2}$ adsorption/desorption isotherms are measured in order to determine the surface area and pore size distribution. The surface area of the different pretreated and heat treated Pinnularia frustules is shown in Table 1. It is observed that the highest surface areas for the cleaned frustules are obtained at $550{ }^{\circ} \mathrm{C}$, probably because at this temperature all organics covering the frustule are removed. The samples treated at $105{ }^{\circ} \mathrm{C}$ have a low surface area because of organics covering the structure. This can be observed in TGA analysis showed that at this temperature pretreated Pinnularia frustules still contained a substantial amount of organic matter which will probably cover the surface. At $750{ }^{\circ} \mathrm{C}$, however, the small pore structures are sintered, resulting in a loss of surface area, as can be seen in Table 1. Fig. 2 shows the pore size distribution of dried frustules treated at $550{ }^{\circ} \mathrm{C}$ and $750{ }^{\circ} \mathrm{C}$. The small pores (up to $20 \mathrm{~nm}$ ) present in the samples treated at $550{ }^{\circ} \mathrm{C}$ have partly disappeared at $750{ }^{\circ} \mathrm{C}$, resulting in the lower surface area. 
Table 1 BET-surface area of Pinnularia frustules derived from $\mathrm{N}_{2}$ adsorption isotherm

\begin{tabular}{|c|c|c|c|c|}
\hline \multirow[b]{3}{*}{ Pretreatment } & \multicolumn{4}{|l|}{ Heat treatment } \\
\hline & $105^{\circ} \mathrm{C}$ & $350{ }^{\circ} \mathrm{C}$ & $550^{\circ} \mathrm{C}$ & $750{ }^{\circ} \mathrm{C}$ \\
\hline & BET-SA $\left(\mathrm{m}^{2} \mathrm{~g}^{-1}\right)$ & BET-SA $\left(\mathrm{m}^{2} \mathrm{~g}^{-1}\right)$ & BET-SA $\left(\mathrm{m}^{2} \mathrm{~g}^{-1}\right)$ & BET-SA $\left(\mathrm{m}^{2} \mathrm{~g}^{-1}\right)$ \\
\hline Dried frustules & 12 & 93 & 101 & 15 \\
\hline Autoclaved frustules & 22 & 113 & 160 & 77 \\
\hline SDS/EDTA treated frustules & 8 & 67 & 59 & 32 \\
\hline $\mathrm{H}_{2} \mathrm{O}_{2}$ treated frustules & 28 & 95 & 85 & 36 \\
\hline $\mathrm{HNO}_{3}$ treated frustules & 24 & 101 & 107 & 77 \\
\hline
\end{tabular}

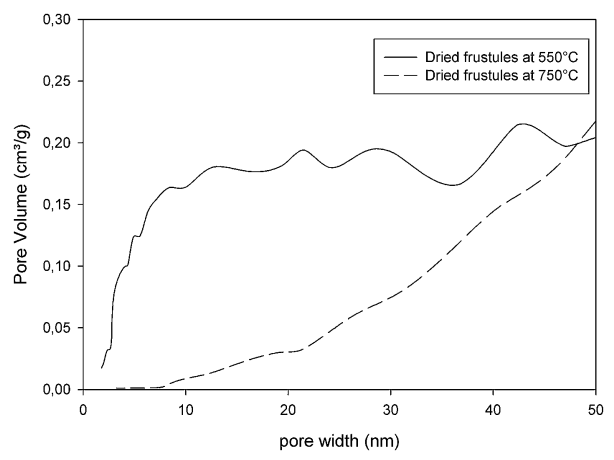

Fig. 2 Pore size distribution of dried Pinnularia frustules calcined at 550 and $750^{\circ} \mathrm{C}$.

\section{FTIR spectroscopy}

The presence of functional groups at the surface of the Pinnularia frustules is investigated by FTIR spectroscopy. FTIR analysis was performed in the range of 400 to $4000 \mathrm{~cm}^{-1}$. Fig. 3 shows the infrared spectra of dried Pinnularia frustules calcined at 105, 350, 550 and $750{ }^{\circ} \mathrm{C}$. All samples have absorption bands at $3444 \mathrm{~cm}^{-1}, 1626 \mathrm{~cm}^{-1}, 1060 \mathrm{~cm}^{-1}$ and $826 \mathrm{~cm}^{-1}$. The bands at 3444 and $1626 \mathrm{~cm}^{-1}$ can be assigned to stretching and bending vibration of surface hydroxyl groups respectively. ${ }^{24}$ The intensity of these bands in the biosilica samples calcined at $550{ }^{\circ} \mathrm{C}$ is much stronger compared to the sample calcined at $750{ }^{\circ} \mathrm{C}$, indicating a loss of surface hydroxyl groups at high temperature. This can be explained by sintering of the pores at high temperature, resulting in a decrease of surface area and thus a loss in surface hydroxyl groups. The absorption band at $826 \mathrm{~cm}^{-1}$ can be assigned to symmetric stretching vibration of the $\mathrm{Si}-\mathrm{O}-\mathrm{Si}$ group $\left(\nu_{\mathrm{S}}(\mathrm{Si}-\mathrm{O}-\mathrm{Si})\right)$, and the $1060 \mathrm{~cm}^{-1}$ absorption band can be attributed to the consequent asymmetric stretching vibration $\left(\nu_{\text {as }}(\mathrm{Si}-\mathrm{O}-\mathrm{Si})\right) \cdot{ }^{25}$ Comparison of the samples calcined at $550{ }^{\circ} \mathrm{C}$ and $105{ }^{\circ} \mathrm{C}$ reveals the appearance of additional adsorption bands at 2915 $\mathrm{cm}^{-1}, 2860 \mathrm{~cm}^{-1}$ and $1545 \mathrm{~cm}^{-1}$. These bands can be assigned to the presence of organic material covering the frustule as for instance $\nu(\mathrm{C}-\mathrm{H})$ and $\nu(\mathrm{N}-\mathrm{H})$ bands. ${ }^{26}$ These $\nu(\mathrm{C}-\mathrm{H})$ and $\nu(\mathrm{N}-\mathrm{H})$ bands have disappeared in the samples calcined at 550 and $750{ }^{\circ} \mathrm{C}$, which indicates that all organics are removed at these temperatures.

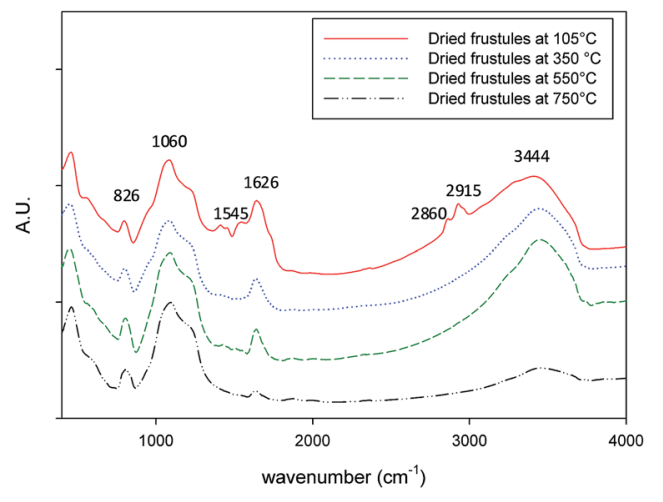

Fig. 3 FTIR analysis of dried Pinnularia frustules treated at different temperatures.

\section{Elemental analysis}

Diatoms are known to bioaccumulate trace levels of metals and incorporate them in the silica cell wall. Different studies have been performed on the metabolic incorporation of elements such as iron, zinc, platinum, titanium and germanium into the silica cell wall. ${ }^{27-30}$ In the cultivation media of the Pinnularia diatoms these elements are present and will be incorporated into the silica cell wall. Table 2 shows the relative distribution of the elements silicium, magnesium, potassium, calcium, manganese, iron, copper, zinc, boron and cobalt in the different pretreated Pinnularia frustules as measured with ICP-MS.

The increase in Si content in the $\mathrm{HNO}_{3}$ treated Pinnularia frustules is due to selective removal of some of the other elements. Elements that are removed are manganese, calcium, magnesium, copper and iron. Salmimies et al. (2011) describes the leaching of iron oxides from ore by nitric acid. ${ }^{31}$ The acid dissolution of iron from the matrix is due to three mechanisms: protonation, complexation and reduction. It is possible to remove some elements present in the silica frustule to obtain a more pure silica structure. Some applications require very pure mesoporous silica that can be achieved by applying a chemical treatment.

\section{Morphology}

The morphology of the different pretreated Pinnularia frustules is studied by using scanning electron microscopy. Fig. 4 shows SEM pictures of the five different pretreatments calcined at 
Table 2 ICP-MS analysis of pretreated Pinnularia frustules calcined at $550^{\circ} \mathrm{C}$

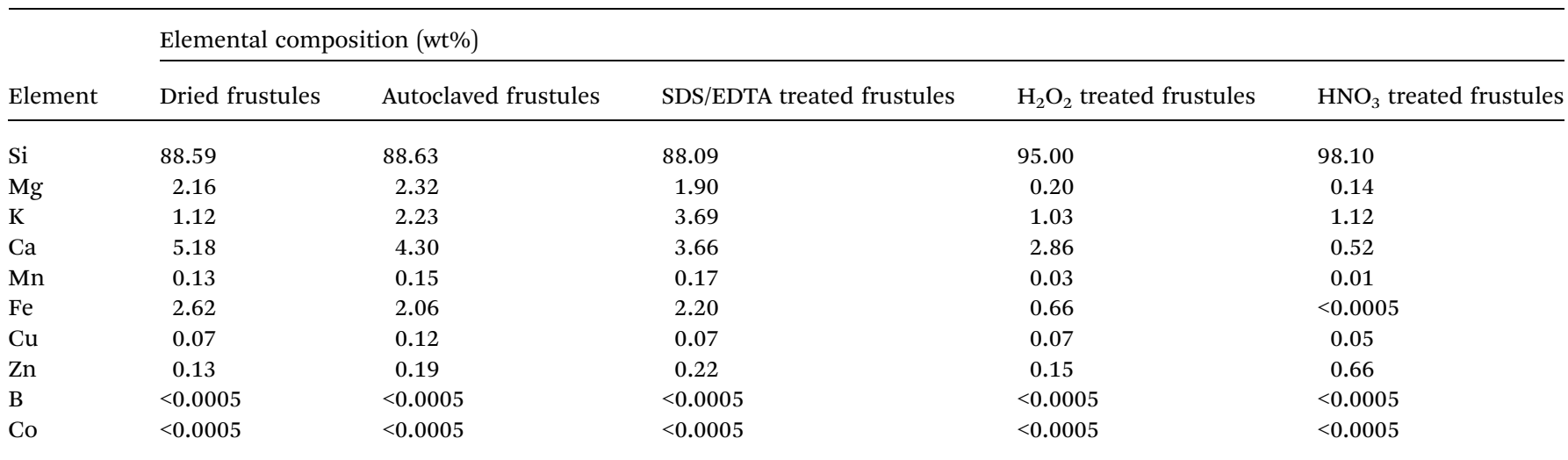

$550{ }^{\circ} \mathrm{C}$. The SEM analysis revealed that the different pretreatment methods resulted in intact frustules. Pinnularia is a raphid pennate diatom specie. ${ }^{32}$ The frustule is characterized by the longitudinal morphology with a length of $30 \mu \mathrm{m}$ and width of 5 $\mu \mathrm{m}$ with pairs of slits along the apical axis. Within these slits small pores are present.

\section{Adsorption of methylene blue}

Adsorption isotherms. The adsorption of methylene blue on pretreated Pinnularia frustules calcined at $550{ }^{\circ} \mathrm{C}$ and $750{ }^{\circ} \mathrm{C}$ is studied. The aim of this study is to test different pretreatment methods in order to obtain purely inorganic Pinnularia frustules. The successful strategies result in porous inorganic silica
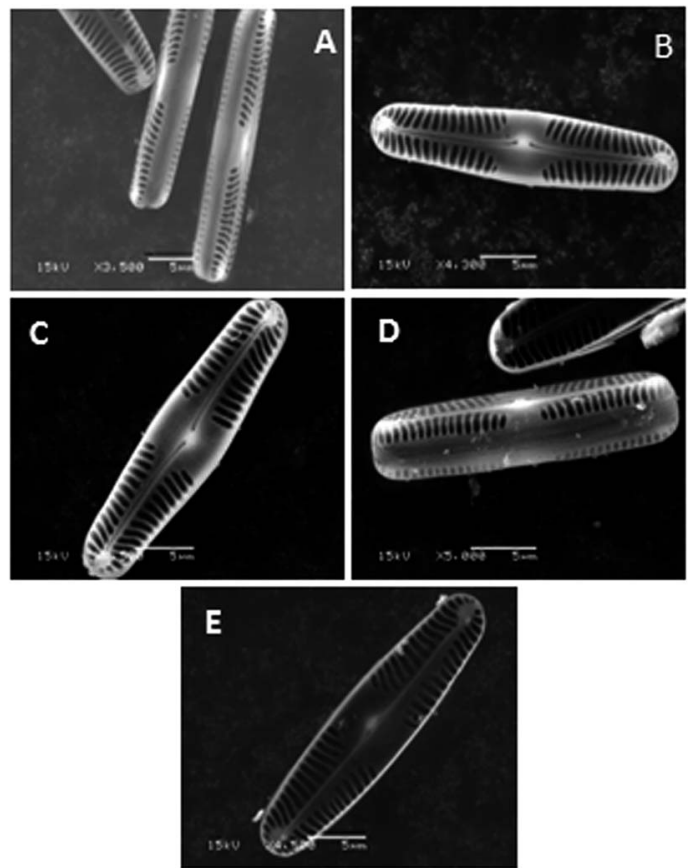

Fig. 4 SEM pictures of pretreated and subsequently calcined at $550^{\circ} \mathrm{C}$ Pinnularia frustules. From top to bottom: dried (A), autoclaved (B), $\mathrm{HNO}_{3}$ treated (C), $\mathrm{H}_{2} \mathrm{O}_{2}$ treated (D) and SDS/EDTA treated (E) Pinnularia frustules. materials that can serve as adsorbents. TGA and FTIR analysis confirm that only calcination of pretreated samples at $550{ }^{\circ} \mathrm{C}$ and $750{ }^{\circ} \mathrm{C}$ is effective in removing the entire organic fraction. The change in material properties of these frustules due to the pretreatment method may affect the adsorption capacity and adsorption process. To investigate these effects, these materials are applied in the adsorption of methylene blue dye in aqueous medium. Adsorption isotherms and maximum adsorption capacity are determined. Fig. 5 displays the non-linear fitting of the equilibrium data by the Langmuir and Freundlich adsorption isotherms. The correlation coefficient $\left(R^{2}\right)$ of the Langmuir model is higher than the Freundlich model, in 9 out of 10 cases, indicating that the Langmuir model is the best suited for fitting the adsorption isotherm of MB on pretreated Pinnularia frustules. A good fit of this equation reflects monolayer adsorption. ${ }^{19}$ The Langmuir adsorption capacity calculated from the fitted Langmuir model is given in Table 3 for all 10 Pinnularia frustules samples.

The Pinnularia frustules calcined at $550{ }^{\circ} \mathrm{C}$ have methylene blue adsorption capacities of $55.3 \mathrm{mg} \mathrm{g}^{-1}, 57.0 \mathrm{mg} \mathrm{g}^{-1}, 8.5 \mathrm{mg}$ $\mathrm{g}^{-1}, 26.2 \mathrm{mg} \mathrm{g}^{-1}$ and $6.8 \mathrm{mg} \mathrm{g}^{-1}$ for dried, autoclaved, SDS/ EDTA treated, $\mathrm{H}_{2} \mathrm{O}_{2}$ treated and $\mathrm{HNO}_{3}$ treated samples, respectively. In these samples no organic material is present as shown by TGA and FTIR. The difference in adsorption capacity between the dried and autoclaved samples and the chemical treated samples can be explained by the combination of elemental composition and surface area. The material characterisation has shown that the chemical cleaning methods can partly or completely remove iron from the frustules. Several studies indicate that methylene blue can adsorb onto iron oxide. $\mathrm{HNO}_{3}$ treated frustules contain no iron resulting in low adsorption of methylene blue.

The difference in the samples calcined at $550{ }^{\circ} \mathrm{C}$ and $750{ }^{\circ} \mathrm{C}$ can be explained by the decrease in surface area. The surface area determines the amount of adsorption sites present in the material. Decrease in surface area will therefore result in a decrease in adsorption capacity. The adsorption of methylene blue onto cleaned frustules is thus highly affected by the material properties of the cleaned Pinnularia frustules. These material characteristics can be altered by the frustule cleaning methods. 

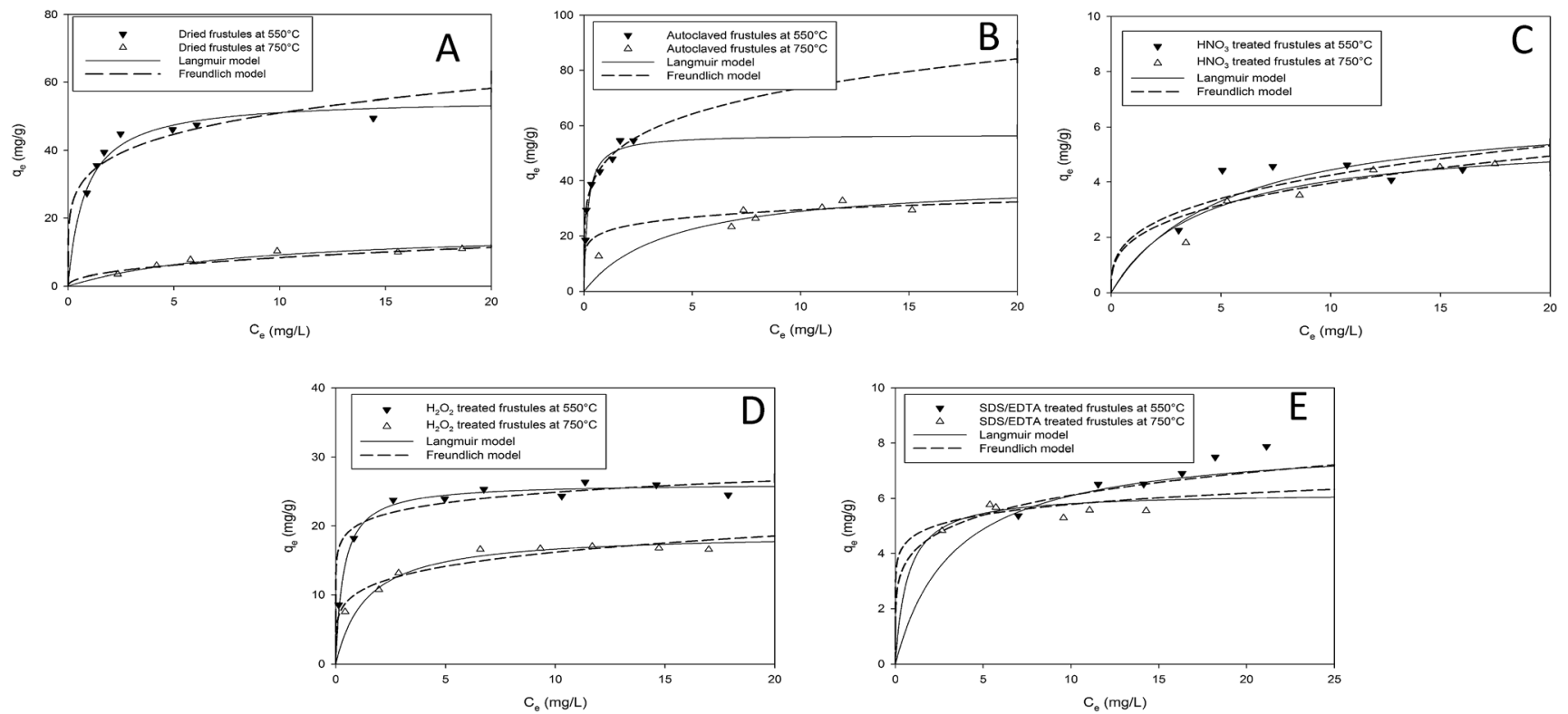

Fig. 5 Non-linear fitting of equilibrium data with Langmuir and Freundlich adsorption isotherm for pretreated Pinnularia frustules. (A) Dried frustules, (B) autoclaved frustules, (C) $\mathrm{HNO}_{3}$ treated frustules, (D) $\mathrm{H}_{2} \mathrm{O}_{2}$ treated frustules, (E) SDS/EDTA treated frustules.

Table 3 Langmuir adsorption capacity of pretreated Pinnularia frustules

\begin{tabular}{lll}
\hline & \multicolumn{2}{l}{ Heat treatment } \\
\cline { 2 - 3 } & $550{ }^{\circ} \mathrm{C}$ & $750{ }^{\circ} \mathrm{C}$ \\
\cline { 2 - 3 } & $Q_{0}\left(\mathrm{mg} \mathrm{g}^{-1}\right)$ & $Q_{0}\left(\mathrm{mg} \mathrm{g}^{-1}\right)$ \\
\hline Pretreatment & 55.3 & 17.0 \\
Dried frustules & 57.0 & 40.5 \\
Autoclaved frustules & 8.5 & 6.2 \\
$\mathrm{SDS}_{\text {EDTA treated frustules }}$ & 26.2 & 19.0 \\
$\mathrm{H}_{2} \mathrm{O}_{2}$ treated frustules & 6.8 & 5.7 \\
$\mathrm{HNO}_{3}$ treated frustules & & \\
\hline
\end{tabular}

\section{Conclusions}

The present study showed that the material properties of Pinnularia frustules derived from freshly cultivated Pinnularia microalgae can be altered by the pretreatment method. The organic matter of freshly cultivated Pinnularia diatoms is removed by different cleaning methods to obtain cleaned Pinnularia frustules. Material characteristics of the different Pinnularia frustules are studied. It is observed that important properties such as specific surface area, elemental composition and organic content are influenced by the used cleaning method. The morphology remains unchanged. Frustules are porous, 3D, hierarchical structures which show great potential for nanotechnological applications. Depending on the application, other properties are required. If high surface area is required, a simple calcination at $550{ }^{\circ} \mathrm{C}$ of autoclaved diatoms is optimal, whereas if high purity of the silica is required, $\mathrm{HNO}_{3}$ treatment is the proper method. The material characteristics can be tuned by using the appropriate pretreatment method.
The different pretreated Pinnularia frustule materials are tested for methylene blue adsorption. The methylene blue adsorption shows that the material characteristics influence the adsorption process. It is observed from the experiments that the maximum adsorption capacity of the Pinnularia frustules is 57 $\mathrm{mg} \mathrm{g}^{-1}$ obtained with autoclaved frustules treated at $550{ }^{\circ} \mathrm{C}$. The best model to fit the equilibrium data was the Langmuir adsorption isotherm, indicating monolayer adsorption.

\section{Acknowledgements}

The authors are thankful to Dr Pieter Vanormelingen for his kind help with the diatom cultivation.

\section{Notes and references}

1 Z. Tao, RSC Adv., 2014, 4, 18961.

2 S. H. Wu, C. Y. Mou and H. P. Lin, Chem. Soc. Rev., 2013, 42, 3862 .

3 H. W. Chen, Y. D. Chiang, C. W. Kung, N. Sakai, M. Ikegami, Y. Yamauchi, K. C. W. Wu, T. Miyasaka and K. C. Ho, J. Power Sources, 2014, 245, 411.

4 A. Galarneau, J. Lapichella, D. Brunel, F. Fajula, Z. BayramHahn, K. Unger, G. Puy, C. Demesmay and J. L. Rocca, J. Sep. Sci., 2006, 29, 844.

5 M. Vialpando, A. Aerts, J. Persoons, J. Martens and G. Van den Mooter, J. Pharm. Sci., 2011, 100, 3411.

6 A. J. Ikushima, T. Fujiwara and K. Saito, J. Appl. Phys., 2000, 88, 1201.

7 H. H. Rao, X. M. Wang, X. Z. Du and Z. H. Xue, Anal. Lett., 2013, 46, 2789.

8 C. Y. Lu, F. S. Su, S. C. Hsu, W. F. Chen, H. L. Bai, J. F. Hwang and H. H. Lee, Fuel Process. Technol., 2009, 90, 1543. 
9 H. E. Townley, A. R. Parker and H. White-Cooper, Adv. Funct. Mater., 2008, 18, 369.

10 D. Losic, J. G. Mitchell and N. H. Voelcker, Adv. Mater., 2009, 21, 2947.

11 C. Jeffryes, J. Campbell, H. Y. Li, J. Jiao and G. Rorrer, Energy Environ. Sci., 2011, 4, 3930.

12 K. D. Bidle and F. Azam, Nature, 1999, 397, 508.

13 M. Hildebrand, A. K. Davis, S. R. Smith, J. C. Trailer and R. Abbriano, Biofuels, 2012, 3, 221.

14 E. G. Vrieling, Q. Y. Sun, M. Tian, P. J. Kooyman, W. W. C. Gieskes, R. A. van Santen and N. A. J. M. Sommerdijk, Proc. Natl. Acad. Sci. U. S. A., 2007, 104, 10441.

15 J. A. Boyle, J. D. Pickett-Heaps and D. B. Czarnecki, J. Phycol., 1984, 20, 563.

16 A. Amato, L. Orsini, D. D'Alelio and M. Montresor, J. Phycol., 2005, 41, 542.

17 K. Umemura, Y. Noguchi, T. Ichinose, Y. Hirose, R. Kuroda and S. Mayama, J. Biol. Phys., 2008, 34, 189.

18 E. Van Eynde, T. Tytgat, M. Smits, S. W. Verbruggen, B. Hauchecorne and S. Lenaerts, Photochem. Photobiol. Sci., 2013, 12, 690.

19 M. A. Al-Ghouti, M. A. M. Khraisheh, M. N. M. Ahmad and S. J. Allen, J. Hazard. Mater., 2009, 165, 589.

20 S. Hong, C. Wen, J. He, F. X. Gan and Y. S. Ho, J. Hazard. Mater., 2009, 167, 630.
21 E. Erdem, G. Çölgeçen and R. Donat, J. Colloid Interface Sci., 2005, 282, 314.

22 J. W. Lund, Biol. Rev., 1965, 40, 231.

23 L. Sicko-Goad, C. L. Schelske and E. F. Stoermer, Limnol. Oceanogr., 1984, 29, 1170.

24 B. Hauchecorne, T. Tytgat, D. Terrens, F. Vanpachtenbeke and S. Lenaerts, Infrared Phys. Technol., 2010, 53, 469.

25 N. Dhiman, B. P. Singh and A. K. Gathania, Colloids Surf., A, 2012, 409, 69.

26 J. J. Mayers, K. J. Flynn and R. J. Shields, Bioresour. Technol., 2013, 148, 215.

27 M. J. Ellwood and K. A. Hunter, Limnol. Oceanogr., 2000, 45, 1517.

28 T. Yamazaki, H. Sasanuma, S. Mayama and K. Umemura, Phys. Status Solidi C, 2010, 7, 2759.

29 C. Jeffryes, T. Gutu, J. Jiao and G. L. Rorrer, ACS Nano, 2008, 2, 2103.

30 C. Jeffryes, T. Gutu, J. Jiao and G. L. Rorrer, Mater. Sci. Eng., C, 2008, 28, 107.

31 R. Salmimies, M. Mannila, A. Häkkinen and J. Kallas, Clays Clay Miner., 2011, 59, 136.

32 C. Souffreau, H. Verbruggen, A. P. Wolfe, P. Vanormelingen, P. A. Siver, E. J. Cox, D. J. Mann, B. Van de Vijver, K. Sabbe and W. Vyverman, Mol. Phylogenet. Evol., 2011, 61, 866. 